\title{
POZYCJA NARODOWEGO BANKU POLSKIEGO W SYSTEMIE NACZELNYCH ORGANÓW WŁADZY PAŃSTWOWEJ
}

\author{
ANALIZA WYBRANYCH ZAGADNIEŃ
}

ABSTRACT The position of the National Bank of Poland in the systemof supreme state authorities. Analysis of selected issues

The National Bank of Poland obtained the status of an independent constitutional body as a result of legal norms and political practice: its organization, functions and powers, and consequently the relationships with supreme state authorities, has significantly changed. The method and shape of regulations made by the legislator is an expression of preference for the entire banking model adopted in Poland: a two-stage model, in which there is one central bank of the state and other commercial banks. The granting of exclusive rights to the NBP to issue money and to formulate and implement monetary policy as well as a prohibition on covering the budget deficit by way of contracting credit obligations to the State's central bank in a meaningful way influenced on the NBP's position: the bank became independent from the executive and the legislature. The control of the bank is limited as the consequence of the bank's political neutrality and high degree of independence. As the result of not sufficient level of democratic supervision the central bank has been deprived of competence to issue generally binding legislation. Although the Polish National Bank is independent, it is obliged to cooperate with other authorities in the formulation and implementation of economic policy, assuming that does not infringe the implementation of monetary policy. NBP does not find his place in the Montesquieu's tripartite separation of powers, but the scope of its functions and constitutional legal grounds justify fully its current position in the state. 
Słowa kluczowe: bank centralny, Narodowy Bank Polski, Prezes NBP, Rada Polityki Pieniężnej, ustrój polityczny Rzeczypospolitej Polskiej

Keywords: central bank, the National Bank of Poland, the President of the NBP, the Monetary Policy Council, the political system of the Republic of Poland

U chwalenie Konstytucji Rzeczypospolitej Polskiej z 2 kwietnia 1997 r. ${ }^{1}$ oraz wejście w życie ustawy o Narodowym Banku Polskim z 29 sierpnia $1997 \mathrm{r}^{2} \mathrm{w}$ istotny sposób zmieniło organizację polskiego banku centralnego, jego funkcje i kompetencje, a w konsekwencji relacje z naczelnymi organami władzy państwowej. Sposób tych regulacji i kształt wprowadzonych przez ustrojodawcę rozwiązań jest wyrazem preferencji co do całego modelu bankowości przyjętego w Polsce: modelu dwustopniowego, w którym istnieje jeden centralny bank państwa oraz inne banki komercyjne. W modelu tym ustanawia się Narodowy Bank Polski jedynym bankiem w Polsce o statusie naczelnego banku państwa oraz podkreśla, że tylko on może wypełniać funkcje charakterystyczne dla centralnego banku państwa. Takie unormowanie musi być rozumiane jako antyteza funkcjonowania NBP jako monobanku - modelu obecnego w czasach Polskiej Rzeczypospolitej Ludowej ${ }^{3}$.

$\mathrm{Na}$ szczególną uwagę zasługuje fakt, że po raz pierwszy problematyka bankowości centralnej oprócz uregulowań zawartych w konkretnej ustawie została również uwzględniona w przepisach ustawy zasadniczej. Konstytucja, podnosząc rangę banku centralnego do konstytucyjnego organu państwa i powierzając mu w art. 227 ust. 1 wyłączne prawo emisji pieniądza oraz ustalania i realizowania polityki pieniężnej, wprowadziła nową jakość w funkcjonowaniu banku. Dodatkowo art. 220 ust. 2 Konstytucji, ustanawiając zakaz pokrywania deficytu budżetowego przez zaciąganie zobowiązań w centralnym banku państwa, ukształtował na nowo autonomię NBP. Powyższe przepisy pozbawiły Sejm formalnego wpływu na określanie założeń polityki pieniężnej, a rząd możliwości częściowego lub całościowego pokrywania braków w budżecie państwa zasobami NBP. Już te dwa unormowania w znaczący sposób wpłynęły na relacje banku z pozostałymi organami państwa, uniezależniając go od władzy wykonawczej i ustawodawczej.

Celem rozważań niniejszego artykułu jest analiza wybranych aspektów ustrojowych, które w znaczący sposób wpłynęły na zmianę w relacjach między bankiem centralnym a naczelnymi organami państwowymi w wyniku transformacji ustrojowej, oraz obrona tezy o słuszności i celowości zastosowanych rozwiązań ustrojowych dotyczących pozycji banku centralnego w Polsce. Motywacją do podjęcia badań w tym zakresie są obecne

Konstytucja Rzeczypospolitej Polskiej z 2 kwietnia 1997 r., Dz. U. 1997, nr 78, poz. 483.

2 Ustawa z 29 sierpnia 1997 r. o Narodowym Banku Polskim, Dz. U. 1997, nr 140, poz. 938 ze zm.

3 M. Zubik, Narodowy Bank Polski (analiza konstytucyjno-ustrojowa), „Państwo i Prawo” 2001, nr 6, s. 38-39. 
w literaturze przedmiotu liczne polemiki i dyskusje poruszające zagadnienie ewolucji pozycji NBP w polskim systemie ustrojowym. W pierwszej kolejności zanalizowany zostanie charakter prawny NBP, następnie omówiony zakres kompetencji prawotwórczych jego organów, na zakończenie z kolei przedstawione zostaną relacje banku z pozostałymi organami, ze szczególnym uwzględnieniem powiązań między niezależnością banku centralnego a zakresem kontroli, jakiemu zostaje poddany.

\section{NARODOWY BANK POLSKI JAKO ORGAN PAŃSTWOWY}

W literaturze przedmiotu, przede wszystkim w doktrynie prawa finansowego i administracyjnego, toczy się polemika co do charakteru prawnego NBP jako podmiotu prawa. Istotnym zagadnieniem dla relacji NBP z pozostałymi organami władzy jest odpowiedź na pytanie, z jakiej pozycji prawnej występuje bank centralny; czy NBP bądź Prezes, Rada Polityki Pieniężnej lub Zarząd NBP - w świetle całokształtu regulacji prawnych - mogą być uznane za organy państwowe? W Konstytucji terminologia odnosząca się do organów państwa jest różnorodna, używane są nazwy „organy władzy publicznej”, „władze publiczne”, „organy władzy państwowej”, „organy państwowe”, „organy administracji publicznej”, „organy samorządu terytorialnego”, „terenowe organy administracji rządowej”, „organy administracji publicznych”, „organy kontroli państwowej i ochrony prawa”.

Marek Zubik definiuje „organ państwa” jako podmiot, który został ustanowiony przez prawo i z mocy prawa wyposażony w jemu właściwe kompetencje do władczego działania w imieniu i na rzecz państwa (wyrażania woli państwa). Prawo stanowione musi zatem łącznie wyodrębnić istniejące realnie podstawy organizacyjne (zasady powoływania, uzupełniania składu i odwoływania), zasady działania (formy i tryb realizacji władczych działań) oraz szczegółowy zakres kompetencji każdego organu. Autor ocenia, że Konstytucja normatywnie wyodrębniła NBP, ale wyodrębnieniu w sferze prawa nie towarzyszyło wyodrębnienie realne (rzeczywiste). Brak precyzyjnie oznaczonych piastunów takiego „organu państwa” powoduje, że na gruncie obecnych przepisów konstytucyjnych i ustawowych nie broni się teza, iż NBP, jako taki, jest organem państwa. Struktura organizacyjna NBP jako banku wymaga dopiero wskazania tych organów, których działanie będzie mogło być rozumiane jako wyraz woli samej instytucji. Dlatego organy NBP, w świetle przyjętej przez autora definicji organu państwa, uznaje on za organy państwa. Za tą tezą przemawia fakt, że wszystkie te podmioty zostały wykreowane przez prawo, prawo określa ich substrat osobowy oraz posiadają one tylko sobie właściwe kompetencje do władczego działania w imieniu i na rzecz państwa (np. RPP - ustalając założenia polityki pieniężnej; Prezes NBP - np. wycofując z obiegu znaki pieniężne; Zarząd - mający wiele kompetencji związanych z instrumentami polityki pieniężnej) $)^{4}$.

Za organ państwa nie uznają również Narodowego Banku Polskiego Ernest Knosal i Rafał Stasikowski. Autorzy podkreślają, iż przepisy Konstytucji RP i ustaw zwykłych

Tamże, s. 32-35. 
nie pozwalają na jasne ustalenie statusu prawnego NBP. Uznają, iż NBP jest szczególnym podmiotem współdecydującym o ustroju państwa polskiego, osobą prawną prawa publicznego, która działa poprzez swoje organy, jednak nie zaliczają go do grona organów państwa. W odmienny sposób określają pozycję jednego z organów banku: Rady Polityki Pieniężnej. Twierdzą, iż RPP jest zarówno organem NBP, jak i szczególnym konstytucyjnym organem państwa polskiego o charakterze wykonawczym. Analiza przepisów regulujących status prawny Rady wskazuje na cechy, które zdaniem autorów sankcjonują włączenie jej do grona organów państwa: jej wyraźne wyodrębnienie, zarówno w strukturze NBP, jak i w instytucjach państwa, działanie w imieniu państwa polskiego, szczegółowe określenie zakresu zadań i kompetencji czy działanie w interesie publicznym 5 .

Odrębne stanowisko na temat pozycji NBP w państwie przedstawia w swych rozważaniach Remigiusz Witold Kaszubski, który powołując się na orzeczenie ${ }^{6}$ Trybunału Konstytucyjnego z 13 września 1990 r. dotyczące aktów prawnych wydawanych przez Prezesa NBP, uznaje, że NBP jest centralnym organem państwa, nową jakościowo instytucją ${ }^{7}$ TK w owym orzeczeniu uznał, iż z ówczesnej ustawowej charakterystyki NBP jako „centralnego banku państwa” wynika, że jest on centralnym organem państwowym w rozumieniu przepisów konstytucyjnych ${ }^{8}$. Określenie „centralny organ państwa” w stosunku do NBP jest w takim razie uwarunkowane konstytucyjnie i ustawowo kompetencjami i funkcjami, jakie spełnia, będąc „centralnym bankiem państwa”. TK dał w swojej uchwale podstawę do wyodrębnienia nowego organu spośród istniejących organów państwowych?

Agnieszka Bień-Kacała i Zbigniew Witkowski zwracają uwagę na to, iż właśnie nie forma organizacyjna powinna odgrywać zasadniczą rolę w definiowaniu organu, ale zakres wykonywanej władzy publicznej oraz brak działalności ze sfery niepublicznej. Dzięki takiemu podejściu bank centralny można zaliczyć do grona organów państwowych ${ }^{10}$. W literaturze przedmiotu spotkać można również koncepcję podwójnej roli NBP w ustroju państwa. Z jednej strony bank centralny postrzegany jest jako instytucja gospodarczo-finansowa, czyli w roli typowej dla banku, z drugiej zaś jako organ państwa ${ }^{11}$.

5 E. Knosala, R. Stasikowski, Status Narodowego Banku Polskiego w systemie organów państwa, „Przegląd Sejmowy" 2010, nr 1, s. 63-73.

6 Orzeczenie Trybunału Konstytucyjnego z 13 września 1990 r., U. 4/90, [online] http://www.trybunal.gov.pl/orzeczenia/teksty/otkpdf/1990/U_04_90.pdf, 10 XI 2013.

7 Zob. A. Mikos, Ustrojowa pozycja banku centralnego w Polsce, Warszawa 2006, s. 87-89, Monografie Prawnicze.

8 Trybunał odnosił się wówczas do ustawy o NBP z 1989 r., której art. 1 brzmiał: Narodowy Bank Polski [...] jest centralnym bankiem państwa, jednak zarówno art. 1 ustawy z 1997 r., jak i art. 227 ust. 1 Konstytucji powtarzają ten przepis.

9 R. W. Kaszubski, Narodowy Bank Polski - centralny organ państwa, „Glosa” 1995, nr 10, s. 2-5.

10 Zob. A. Bień-Kacała, Z. Witkowski, Opotrzebie redefinicji terminu „organ państwa”, [w:] W stużbie dobru wspólnemu. Ksiega jubileuszowa dedykowana Profesorowi Januszowi Trzcińskiemu, red. R. Balicki, M. Masternak-Kubiak, Warszawa 2012, s. 404-410.

11 M. Zdebel, Status konstytucyjny Narodowego Banku Polskiego, [w:] Ksiega pamiątkowa profesora Marcina Kudeja, red. nauk. A. Łabno, E. Zwierzchowski, Katowice 2009, s. 157. 
W polemice dotyczącej charakteru prawnego NBP wypowiadają się również zwolennicy tezy, że ani banki centralne, ani ich organy wewnętrzne nie są organami państwa. Oczywiście umiejscowienie przepisów dotyczących banku i jego organów w ustawie zasadniczej nie pozostaje bez znaczenia dla oceny ich charakteru prawnego, jednak nawet bardzo szczegółowe unormowania konstytucyjne nie przesądzają o zakwalifikowaniu banku i jego organów do grupy organów państwa ${ }^{12}$.

Wreszcie w rozważaniach nad wspomnianym wyżej zagadnieniem pojawia się przekonanie, iż nie sposób jednoznacznie określić statusu prawnego $\mathrm{NBP}^{13}$. Autorem tego poglądu jest Cezary Kosikowski, który w swej analizie wyklucza pozycję banku jako przedsiębiorstwa państwowego (mimo ustawowo określonej siedziby, ustawa stanowi, że nie podlega on wpisowi do rejestru przedsiębiorstw państwowych), zwraca uwagę na samodzielną gospodarkę finansową NBP, która wskazuje, że bank nie jest dysponentem części budżetowej w budżecie państwa - cechy charakterystycznej dla podmiotów pełniących funkcję organów naczelnych lub centralnych. Następnie podkreśla, że do działalności NBP nie stosuje się przepisów ustawy Prawo bankowe, z czego wynika, że NBP nie jest bankiem państwowym w rozumieniu tej ustawy. Na koniec autor wyklucza również tezę, że NBP jest organem administracji publicznej (państwowej). Zdaniem Kosikowskiego NBP jest centralnym bankiem państwa, co powszechnie oznacza sytuację odrębną od innych banków i od innych podmiotów prawnych. Wobec tego wszelkie porównania pozycji NBP z innymi podmiotami nie są uprawnione i stają się przez to jałowe $e^{14}$.

Podsumowując przedstawione wyżej stanowiska w polemice na temat charakteru prawnego Narodowego Banku Polskiego, za uzasadnioną należy uznać tezę, że NBP jest organem państwa. Stanowisko to zostało potwierdzone w wyroku ${ }^{15}$ Trybunału Konstytucyjnego z 26 maja 1998 r. Trybunał przyjął, że do uznania danego organu za „konstytucyjny organ państwa” konieczne jest, aby bezpośrednio na gruncie samych przepisów Konstytucji spełniony został co najmniej jeden z warunków: w tekście ustawy zasadniczej wymieniona została nazwa tego organu, określony został tam sposób jego utworzenia bądź wyodrębnienia jego struktury organizacyjnej, przesądzono kwestie jego kadencyjności, przyznane mu zostały wyraźnie określone kompetencje bądź nastąpiło określenie relacji między tym organem władzy a innymi organami państwa ${ }^{16}$. W odniesieniu do Narodowego Banku Polskiego wszystkie te warunki zostały spełnione na gruncie samych przepisów Konstytucji RP:

12 T. Machelski, Charakter prawny Rady Polityki Pieniężnej, „Przegląd Legislacyjny” 2009, nr 3/4, s. 59, 62; tenże, Stanowienie polityki pieniężnej w Polsce na tle instytucjonalnych standardów bankowości centralnej, „Problemy w Wpółczesnego Prawa Międzynarodowego, Europejskiego i Porównawczego” 2010, Vol. 8, s. 172-174, 177-178.

13 Por. M. Zdebel, Status konstytucyjny..., s. 158.

14 C. Kosikowski, Pozycja Narodowego Banku Polskiego i jego organów w prawie polskim, „Państwo i Prawo" 2002, nr 11, s. 20-21.

15 Wyrok Trybunału Konstytucyjnego z dnia 26 maja 1998 r., K. 17/98, [online] http://www.trybunal. gov.pl/orzeczenia/teksty/otkpdf/1998/k_17_98.pdf, 10 XI 2013.

16 M. Zubik, Narodowy Bank Polski..., s. 36-37. 
- nazwa centralnego banku państwa pojawia się w kilku artykułach ustawy zasadniczej, m.in. w art. 227 ust. 1: centralnym bankiem państwa jest Narodowy Bank Polski;

- struktura organizacyjna banku przedstawiona jest w art. 227 ust. 2 poprzez wymienienie jego organów (Prezes NBP, Rada Polityki Pieniężnej oraz Zarząd NBP); w dalszej części artykuł ten określa kadencyjność i sposób wyboru Prezesa oraz Rady Polityki Pieniężnej;

- kompetencje NBP są sprecyzowane w ust. 1 art. 227, który stanowi, iż Narodowemu Bankowi Polskiemu przystuguje wytaczne prawo emisji pieniadza oraz ustalania i realizowania polityki pieniężnej;

- przepisy określające relacje między NBP a innymi organami państwowymi znajdują się w: art. 227 ust. 6, który nakłada na Radę Polityki Pieniężnej obowiązek przedłożenia do wiadomości Sejmowi corocznych założeń polityki pieniężnej oraz złożenia sprawozdania z wykonania założeń polityki pieniężnej; art. 198 ust. 1, który stanowi, iż Prezes Narodowego Banku Polskiego za naruszenie konstytucji lub ustawy, w związku z zajmowanym stanowiskiem lub w zakresie swojego urzędowania, ponosi odpowiedzialność konstytucyjną przed Trybunałem Stanu; art. 203 ust. 1, który ustanawia, iż Najwyższa Izba Kontroli kontroluje dziatalność [...] Narodowego Banku Polskiego z punktu widzenia legalności, gospodarności, celowości i rzetelności.

Nie budzi więc zastrzeżeń przyznanie NBP statusu organu państwa, ponieważ spełnia wszystkie warunki wymagane przez Trybunał Konstytucyjny w orzeczeniu z 26 maja 1998 r., aby uznać dany organ za „konstytucyjny organ państwa”.

\section{CHARAKTER PRAWNY AKTÓW WYDAWANYCH PRZEZ ORGANY NBP}

Jako organ państwowy NBP został wyposażony w jemu tylko właściwe funkcje i kompetencje. Mimo iż realizując je, uznawany jest za wysoce niezależny, to nowe regulacje prawne zmieniły charakter aktów prawnych wydawanych przez organy banku: wyłączono je z kategorii źródeł prawa powszechnie obowiązującego, uszczuplając w ten sposób uprawnienia banku. W gospodarce sterowanej dyrektywnie przez państwo centralny bank państwa był uznawany za organ zarządzania gospodarką narodową i wydawane przez jego prezesa akty normatywne były zaliczane do źródeł prawa. Przejście z gospodarki planowej na gospodarkę rynkową w Polsce, uchwalenie nowej Konstytucji i ustawy o NBP zmieniły ten stan rzeczy. Zgodnie z ustawą o Narodowym Banku Polskim Prezes NBP może wydawać zarządzenia (art. 11 ust. 4 ustawy o NBP), Zarząd NBP podejmuje uchwały (art. 19 ustawy o NBP), Rada Polityki Pieniężnej wyraża swoje decyzje i stanowiska również w formie uchwał (art. 16 ust. 3 ustawy o NBP) ${ }^{17}$. NBP stracił uprawnienie do wydawania aktów wykonawczych o mocy powszechnie obowiązującej,

Zob. A. Mikos, Ustrojowa pozycja..., s. 128-130. 
o czym świadczy zamknięty system źródeł prawa zawarty w Konstytucji ${ }^{18}$. Rozdział III Konstytucji RP, poświęcony źródłom prawa, wychodzi z założenia, że system źródeł prawa jest - zarówno od strony przedmiotowej, jak i podmiotowej - zamknięty w samej Konstytucji. W rezultacie źródłami prawa w rozumieniu Konstytucji są tylko akty prawne wymienione w samej Konstytucji, które mogą być stanowione wyłącznie przez organy i podmioty również wprost określone w Konstytucji:

- ograniczenia przedmiotowe - Konstytucja wskazuje, że źródłami prawa powszechnie obowiązującymi w Rzeczpospolitej Polskiej są poza nią samą: ustawy, ratyfikowane umowy międzynarodowe, rozporządzenia (art. 87 ust. 1) oraz akty prawa miejscowego na obszarze działania organów, które je ustanowiły (art. 87 ustęp 2); rozporządzenia mogą wydawać tylko organy wskazane w Konstytucji, na podstawie szczegółowego upoważnienia, zawartego w ustawie i w celu jej wykonania (art. 92 ust. 1).

- ograniczenia podmiotowe - Ustawa zasadnicza zakreśla krąg organów upoważnionych do stanowienia prawa powszechnie obowiązującego; są to: Sejm i Senat (art. 95 ust. 1, art. 118-124), Prezydent RP (art. 142 ust. 1), Rada Ministrów (art. 146 ust. 4 pkt 2), minister kierujący działem administracji rządowej (art. 149 ust. 2), przewodniczący komitetu powołany w skład Rady Ministrów (art. 149 ust. 3) oraz Krajowa Rada Radiofonii i Telewizji (art. 213 ust. 2) ${ }^{19}$.

Dodatkowym potwierdzeniem braku uprawnienia organów NBP do wydawania norm prawa powszechnie obowiązującego był wyrok ${ }^{20}$ Trybunału Konstytucyjnego z 28 czerwca 2000 r. ${ }^{21}$ Zdaniem Trybunału analiza Konstytucji, a zwłaszcza jej rozdziału III, nie pozostawiała wątpliwości, że ustrojodawca w sposób jednoznaczny i zamierzony przyjął w Konstytucji przedmiotowo i podmiotowo zamknięty system źródeł prawa powszechnie obowiązującego. Trybunał podkreślił, że specyficzna pozycja ustrojowa NBP jako centralnego banku państwa polega z jednej strony na jego niezależności od organów państwowych, z drugiej zaś na jego „apolityczności”. Nie jest on więc organem politycznym, któremu z racji określonych zadań przypisane zostały określone kompetencje prawotwórcze. Kompetencje takie oznaczałyby udział w procesie tworzenia prawa, w tym sensie miałyby więc charakter polityczny. Jednocześnie Trybunał zwrócił uwagę na możliwość użycia przez NBP innych instrumentów prawnych w celu dostosowania działalności banków komercyjnych i innych podmiotów do ustalonych przez siebie założeń polityki pieniężnej. Przywołany został tu art. 227 ust. 1 Konstytucji i pojęcie czynności należącej do wyłącznej gestii NBP, a mianowicie „ustalania” polityki pieniężnej. W ocenie Trybunału znamienne dla tego przepisu „ustalanie” oznacza okre-

18 C. Kosikowski, Finansepubliczne ws świetle Konstytucji RP oraz orzecznictwa Trybunatu Konstytucyjnego (na tle porównawczym), Warszawa 2004, s. 261-262, 269.

19 M. Kulesza, „Źródta prawa” i przepisy administracyjne w świetle nowej Konstytucji, „Państwo i Prawo” 1998, nr 2, s. 12-13.

20 Wyrok Trybunału Konstytucyjnego z dnia 28 czerwca 2000 r., K. 25/99, [online] http://www.trybu nal.gov.pl/orzeczenia/teksty/otkpdf/2000/k_25_99.pdf, 10 XI 2013.

21 Szerzej na ten temat zob.: Konstytucyjność regulacji Rady Polityki Pieniężnej i NBP, Orzeczenie TK, „Glosa” 2000, nr 11. 
ślanie pewnych norm i reguł oddziaływania na gospodarkę w celu osiągania założonych rezultatów. Owo oddziaływanie z reguły będzie polegać na korzystaniu z instrumentów klasycznych (finansowych i ekonomicznych), jednakże niejednokrotnie może wymagać władczej ingerencji, a więc instrumentów bezpośrednich.

Mimo tak jasnej wykładni omawianego zagadnienia w literaturze przedmiotu i praktyce ustrojowej pojawiały się różne, często sprzeczne, opinie na temat braku wyposażenia organów Narodowego Banku Polskiego w możliwość wydawania aktów o charakterze powszechnie obowiązującym:

- Narodowy Bank Polski stał na stanowisku, iż (zgodnie zart. 227 ust. 1 Konstytucji) posiada własne i wyłączne uprawnienia, a jego status charakteryzuje się niezależnością od władzy ustawodawczej i władzy wykonawczej. Dla realizacji jego konstytucyjnych zadań ustrojodawca nie dał NBP odpowiednich instrumentów prawnych, tj. prawa do wydawania rozporządzeń jako podustawowych aktów wykonawczych o charakterze powszechnie obowiązującym, aczkolwiek stosowne klauzule „wykonawcze” zawierają ustawy zwykłe, uchwalone wprawdzie przed wejściem w życie Konstytucji RP, ale już po zatwierdzeniu jej przez naród w referendum. W tym kontekście nie można zgodzić się z interpretacją NBP, iż fakt ten należy odczytywać jako wolę parlamentu, by takim działaniem „przełamać” sprzeczność wewnątrz Konstytucji na rzecz wyposażenia NBP w „odpowiednie” (jego zdaniem) uprawnienia prawotwórcze, tj. prawo stanowienia przepisów powszechnie obowiązujących. Przyjęcie takiego założenia oznaczałoby przypisywanie parlamentowi chęci nieprzestrzegania Konstytucji ${ }^{22}$.

- Rozwiązanie to było uznane są za celowe i prawidłowe - akty normatywne mogą stanowić jedynie organy państwa, ponoszące polityczną odpowiedzialność za swoje działania (Prezes NBP jest natomiast organem apolitycznym).

- Rozwiązanie to było uznane za błąd Komisji Konstytucyjnej. Proponowano usunięcie wadliwego uregulowania poprzez zmianę Konstytucji, pozwalającą zaliczyć Prezesa NBP do kategorii organów „wskazanych” w Konstytucji do wydawania powszechnie obowiązujących rozporządzeń. Gdyby uznać ten pogląd za zasadny, to w obliczu przeniesienia przez ustawę o NBP dotychczasowych uprawnień stanowiących Prezesa NBP na organy kolegialne (Radę Polityki Pieniężnej i Zarząd) należałoby w roli organów „wskazanych” w Konstytucji wymienić wszystkie trzy organy NBP. O nieświadomie popełnionym błędzie Komisji Konstytucyjnej nie może być jednak mowy, ponieważ w trakcie dyskusji nad art. 216 projektu Konstytucji (ostatecznie uzyskał on oznaczenie jako art. 227) propozycja dodania ust. 4a, upoważniającego Prezesa NBP do wydawania rozporządzeń, po dyskusji została ostatecznie odrzucona jako niespójna z przyjętą wcześniej koncepcją zamkniętego systemu źródeł prawa ${ }^{23}$.

22 A. Szmyt, $W$ sprawie uprawnień prawodawczych organów Narodowego Banku Polskiego, „Przegląd Sejmowy" 1998, nr 6, s. 71.

23 R. Tupin, Status prawny i kompetencje prawotwórcze organów Narodowego Banku Polskiego i Komisji Nadzoru Bankowego, „Przegląd Ustawodawstwa Gospodarczego” 1998, nr 7-8, s. 5. 
- Pojawiła się propozycja, aby wykorzystać przepis przejściowy Konstytucji (art. 241 ust. 6), na podstawie którego Rada Ministrów w okresie dwóch lat od dnia wejścia w życie Konstytucji ustali, które z uchwał Rady Ministrów oraz zarządzeń ministrów lub innych organów administracji rządowej podjęte lub wydane przed dniem wejścia w życie Konstytucji wymagają - stosownie do warunków określonych w art. 87 ust. 1 i art. 92 Konstytucji - zastąpienia ich przez rozporządzenia wydane na podstawie upoważnień ustawy, której projekt w odpowiednim czasie Rada Ministrów przedstawi Sejmowi. Przepis ten miał być podstawą wydawania zarządzeń przez Prezesa NBP, do czasu zmiany Konstytucji.

- Opiniowano, że należy dokonywać aktywnej interpretacji Konstytucji, która, nie naruszając jej postanowień, zadośćuczyni potrzebom praktyki. Jako argument podana była teza, iż Konstytucja z natury jest aktem tak ogólnym, że wymaga wykładni, a wykładnia ta pozwala uznać, że zarządzenia Prezesa NBP nie będą miały charakteru wewnętrznego, ale wychodzący na zewnątrz, wynikając z samoistnych zadań $\mathrm{NBP}^{24}$.

Podsumowując, należy zgodzić się z opinią o celowości i prawidłowości obowiązujących rozwiązań prawnych dotyczących kompetencji prawotwórczych organów NBP. Artykuł 2 Konstytucji RP stanowi, iż Rzeczpospolita Polska jest demokratycznym państwem prawnym [...]. Jednym z założeń funkcjonowania demokratycznego państwa prawnego jest zasada, wedle której działalność państwa opiera się na zasadzie legalności oraz podziału i wzajemnej kontroli władz. Ze względu na apolityczność oraz niezależność Narodowego Banku Polskiego kontrola, jakiej podlega bank, jest celowo w dużym stopniu ograniczona, a co za tym idzie - niewystarczająca dla organu, który byłby uprawniony do wydawania norm prawa powszechnie obowiązującego. Nie powinno się zatem „na siłę” do grona tych organów włączać Narodowego Banku Polskiego, gdyż byłoby to niezgodne z prawem.

\section{RELACJE BANKU CENTRALNEGO Z ORGANAMI PAŃSTWOWYMI}

Nowa Konstytucja i ustawa o NBP w miejsce jednoosobowego kierownictwa bankiem dokonała faktycznego trójpodziału władzy, a każdy z trzech organów - Prezes, Rada Polityki Pieniężnej oraz Zarząd (art. 227 ust. 2 Konstytucji RP oraz art. 6 ustawy o NBP) - powoływany jest w osobnym trybie. Już sam etap powoływania, jak również odwoływania, poszczególnych organów banku nakreśla wstępnie koncepcję relacji ustrojowych między bankiem centralnym a pozostałymi władzami.

Ustawa o NBP normuje tryb powoływania i odwoływania wszystkich trzech organów banku, natomiast ustrojodawca podkreśla rangę Prezesa NBP i RPP poprzez umieszczenie przepisów dotyczących ich powoływania również w samej Konstytucji. Prezes NBP, który pełni funkcje przewodniczącego RPP i Zarządu NBP, powoływany jest przez Sejm

24 S. Niemierka, Pozycja Prezesa NBP w „ustawach bankowych”, „Glosa” 1998, nr 8, s. 9. 
bezwzględną większością głosów na wniosek Prezydenta RP. Wniosek Prezydenta do Sejmu o jego powołanie nie jest obostrzony wymogiem podpisu Prezesa Rady Ministrów, a więc jest autonomiczną decyzją głowy państwa. Ważnym elementem uniezależniającym pozycję Prezesa jest przyznanie mu kadencji długiej, dłuższej niż prezydenta oraz władzy ustawodawczej, bo aż sześcioletniej. Ta długotrwała kadencja dotyczy również urzędowania członków RPP, którzy powoływani są w równej licznie przez Prezydenta RP, Sejm i Senat spośród specjalistów z zakresu finansów oraz Zarządu NBP, którego członkowie z kolei powoływani są przez Prezydenta RP na wniosek Prezesa NBP.

Konstytucja RP nie wypowiada się na temat odwołania Prezesa NBP, co niektórzy uznają za wyraz trwałości piastowania tego urzędu przez całą jego kadencję i brak możliwości odwołania go w trakcie jej trwania. Ustawa o NBP doskonale uzupełnia te luki. Kadencja Prezesa NBP wygasa po upływie okresu sześcioletniego (z zastrzeżeniem, iż Prezes wypełnia obowiązki do czasu objęcia obowiązków przez nowo wybranego Prezesa NBP), w razie śmierci ${ }^{25}$, złożenia rezygnacji oraz w razie odwołania. Odwołanie Prezesa NBP z funkcji w trakcie kadencji może nastąpić jedynie na skutek złożenia przez niego rezygnacji oraz w ustawowo określonych przypadkach, gdy:

- nie wypełnia on swoich obowiązków na skutek długotrwałej choroby;

- został skazany prawomocnym wyrokiem sądu za popełnione przestępstwo;

- złożył niezgodne z prawdą oświadczenie lustracyjne, stwierdzone prawomocnym orzeczeniem sądu;

- Trybunał Stanu orzekł wobec niego zakaz zajmowania kierowniczych stanowisk lub pełnienia funkcji związanych ze szczególną odpowiedzialnością w organach państwowych.

W tych wypadkach wniosek o odwołanie Prezesa NBP powinien zostać przedstawiony Sejmowi przez Prezydenta RP, chociaż teza ta nie wynika wprost z żadnego przepisu prawnego.

Możliwość skrócenia kadencji członków RPP i Zarządu jest równie ściśle limitowana i częściowo zbieżna z warunkami dotyczącymi stanowiska Prezesa NBP. Organy powołujące mogą odwołać członków RPP lub Zarządu przez upływem kadencji wyłącznie w następujących przypadkach:

- zrzeczenia się swej funkcji;

- choroby trwale uniemożliwiającej sprawowanie funkcji;

- skazania prawomocnym wyrokiem sądu za popełnienie przestępstwa;

- złożenia niezgodnego z prawdą oświadczenia lustracyjnego, stwierdzonego prawomocnym orzeczeniem sądu;

25 Okoliczności wyboru Marka Belki na stanowisko Prezesa NBP były związane z tragicznymi wydarzeniami katastrofy smoleńskiej, w której zginął jego poprzednik Sławomir Skrzypek. Ustawa o NBP nie wskazywała dokładnie zastępcy, który przejąłby obowiązki Prezesa w razie zakończenia tejże kadencji. Ustawa z 21 maja 2010 r. o zmianie ustawy o Narodowym Banku Polskim uzupełniła tę lukę, wprowadzając przepis w art. 9a wskazujący na wiceprezesa NBP - pierwszego zastępcę Prezesa NBP - jako pełniącego obowiązki Prezesa NBP. Pomimo braku tak explicite przepisu w ustawie w momencie katastrofy smoleńskiej to właśnie Piotr Wiesiołek, wiceprezes NBP - pierwszy zastępca Prezesa NBP przejął obowiązki Prezesa NBP od 10 kwietnia do 11 czerwca 2010 r. 
- niezawieszenia działalności w partii politycznej lub związku zawodowego na okres kadencji w Radzie bądź Zarządzie.

W rozwiązaniach tych widoczna jest dbałość ustawodawcy, aby kadencja organów nie była zakłócana przez pozostałe organy państwowe. Przyczynia się do tego zarówno enumeratywne wyliczenie powodów odwołania, jak również ich konkretne okoliczności, np. powodem odwołania nie jest złe wypełnianie obowiązków, jeśli nie towarzyszy temu długotrwała choroba, w stosunku do Prezesa nie jest nim nawet wyrok skazujący wydany przez Trybunał Stanu, a jedynie orzeczona przezeń kara w postaci zakazu zajmowania określonych stanowisk.

Jako bank państwa NBP współpracuje z właściwymi organami państwa, a także świadczy różnorodne usługi finansowe na rzecz organów państwa i niektórych jednostek państwowych. Unormowania prawne poświęcone stosunkowi banku centralnego do organów państwowych stanowią odrębny rozdział (rozdz. 3 art. 21-24) w ustawie o NBP. Ustalono w nim przede wszystkim zasadę współdziałania NBP i organów państwowych, a także przedmiot i niektóre jego formy. NBP ma w wykonaniu swoich zadań kooperować z właściwymi organami państwa w kształtowaniu i realizacji polityki gospodarczej państwa, dążąc przy tym do zapewnienia należytej realizacji założeń polityki pieniężnej (art. 21). W tym celu:

- przekazuje organom państwa założenia polityki pieniężnej oraz informacje dotyczące realizacji polityki pieniężnej i sytuacji w systemie bankowym;

- współdziała z ministrem finansów w opracowaniu planów finansowych państwa;

- opiniuje projekty aktów normatywnych z zakresu polityki gospodarczej;

- opiniuje projekty aktów normatywnych dotyczących działalności banków i mających znaczenie dla systemu bankowego (art. 21 ustawy o NBP);

- prezes NBP może uczestniczyć w posiedzeniach Sejmu (art. 22 ustawy o NBP).

Ponadto w imieniu Rady Prezes NBP przedstawia Sejmowi i Radzie Ministrów kwartalne informacje o bilansie płatniczym oraz roczne zestawienie międzynarodowej pozycji inwestycyjnej, natomiast Radzie Ministrów i ministrowi finansów przekazuje projekty założeń polityki pieniężnej, opinie w sprawie projektu ustawy budżetowej, prognozy bilansu płatniczego oraz ustalenia Rady Polityki Pieniężnej, a także informacje o wpłatach (wypłatach) z zysku do budżetu państwa (art. 23 ustawy o NBP) ${ }^{26}$. Prezes NBP jako członek Komitetu Stabilności Finansowej (art. 22a ustawy o NBP) wraz z ministrem finansów oraz przewodniczącym Komisji Nadzoru Finansowego działa na rzecz wspierania i utrzymania stabilności krajowego systemu finansowego poprzez wymianę informacji, opinii i ocen sytuacji w systemie finansowym w kraju i za granicą oraz koordynację działań w tym zakresie (art. 1 ust. 2 ustawy o Komitecie Stabilności Finansowej).

Świadczone przez NBP organom państwa usługi sprowadzają się przede wszystkim do:

- reprezentowania przez Prezesa NBP interesów Polski w międzynarodowych instytucjach bankowych, a także - o ile Rada Ministrów nie postanowi inaczej w międzynarodowych instytucjach finansowych (art. 11 pkt 3 ustawy o NBP);

26 C. Kosikowski, Pozycja Narodowego Banku Polskiego..., s. 23. 
- realizacji polityki walutowej, ustalonej przez Radę Ministrów w porozumieniu z Radą Polityki Pieniężnej; zasady ustalania kursu złotego w stosunku do walut obcych ustala rząd w porozumieniu z Radą, do zadań NBP należy zaś ogłaszanie bieżących kursów walut obcych oraz kursów innych wartości dewizowych (art. 24 ustawy o NBP);

- pełnienia na podstawie umowy zawieranej każdorazowo z ministrem finansów funkcji agenta finansowego rządu w zakresie zawierania i realizacji umów kredytowych oraz obsługi zadłużenia zagranicznego państwa (art. 52 pkt 3 ustawy o NBP);

- prowadzenia rachunków budżetu państwa (art. 51 pkt 1 ustawy o NBP);

- przeprowadzania powierzonej bankowi centralnemu obsługi pożyczki państwowej, zaciągniętej przez emisję papierów wartościowych (art. 49 ustawy o NBP) ${ }^{27}$.

Współdziałanie innych podmiotów z NBP ma z kolei polegać na tym, że naczelne organy państwowe, organy administracji rządowej i samorządu terytorialnego, banki $i$ inne osoby prawne, jednostki organizacyjne niebędące osobami prawnymi oraz inni przedsiębiorcy mają przekazywać na żądanie NBP dane niezbędne do ustalania polityki pieniężnej i okresowych ocen sytuacji pieniężnej państwa, natomiast podmioty uczestniczące w obrotach z zagranicą przekazują NBP dane niezbędne do sporządzenia bilansu płatniczego oraz międzynarodowej pozycji inwestycyjnej. Podmioty uczestniczące w rozliczeniach pieniężnych i rozrachunkach międzybankowych są zobowiązane do przekazywania, na żądanie NBP, danych niezbędnych do dokonywania ocen funkcjonowania rozliczeń pieniężnych i rozrachunków międzybankowych. Z kolei banki przekazują na żądanie NBP dane niezbędne do oceny ich sytuacji finansowej oraz stabilności i ryzyka sektora bankowego (art. 23 ustawy o NBP).

Warte pogłębienia w obliczu poruszanej problematyki jest zagadnienie współpracy NBP z rządem. W okresie, gdy istniała zależność NBP od rządu i ministra finansów, budżet państwa dla zmniejszenia lub pokrycia deficytu budżetowego wspierał się na zasobach banku centralnego. Obecne rozwiązania prawne, wprowadzając zakaz pokrywania deficytu budżetowego przez zaciąganie zobowiązania w centralnym banku państwa (art. 220 ust. 2 Konstytucji) ${ }^{28}$, uniezależniły bank w tym aspekcie od władzy wykonawczej. Jednakże niezależność banku centralnego od instrukcji rządu nie jest równoznaczna $\mathrm{z}$ działalnością $\mathrm{w}$ państwie autonomicznych ośrodków decyzyjnych. Wieloaspektowa staje się odpowiedź na pytanie o możliwość prowadzenia polityki pieniężnej przez centralny bank państwowy niezależnie od rządu. Według art. 227 ust. 1 Konstytucji Narodowemu Bankowi Polskiemu przysługuje wyłączne prawo emisji pieniądza, ustalania i realizowania polityki pieniężnej oraz dbałość o wartość polskiego pieniądza. Takie sformułowanie celu działalności banku centralnego jest podkreśle-

27 K. Koperkiewicz-Mordel, Polski bank centralny w świetle nowej Konstytucji i ustawy o Narodowym Banku Polskim, „Bank i Kredyt” 1998, nr 3, s. 13-14.

28 W ciągu roku od dnia wejścia w życie Konstytucji (17 października 1997 r.) w ustawie budżetowej (na 1998 r.) była możliwość pokrywania deficytu budżetowego poprzez zaciąganie zobowiązań w centralnym banku państwa (art. 240 Konstytucji RP). 
niem jego niezależnych kompetencji. Z kolei z art. 3 ust. 1 ustawy o NBP wynika już obowiązek współdziałania z rządem. Przepis ten, określając utrzymanie stabilnego poziomu cen jako podstawowy cel działalności NBP, nakazuje mu jednoczesne wspieranie polityki gospodarczej rządu, o ile nie ogranicza to celu podstawowego.

W pierwotnej wersji ustawy o NBP znajdował się również przepis umieszczony w art. 15, który przewidywał udział przedstawiciela rządu w posiedzeniach Rady Polityki Pieniężnej. Co prawda nie miał on prawa udziału w głosowaniu, jednak mógł przedstawić wnioski do rozważenia przez Radę. Możliwość ta została usunięta zmianą ustawy z 18 grudnia 2003 r., co wskazuje na zamiar ustawodawcy zwiększenia autonomiczności funkcjonowania Rady, a co za tym idzie banku centralnego.

Pewne zastrzeżenia specjalistów w zakresie finansów wzbudzają przepisy art. 24 ust. 1 i 2 ustawy o NBP - politykę walutową oraz zasady ustalania kursu złotego wobec walut obcych określa Rada Ministrów w porozumieniu z RPP, a NBP wykonuje ustalenia. Uważają oni, że bank centralny nie jest w stanie skutecznie realizować niezależnej polityki pieniężnej, gdy decyzje w sprawie kursów walutowych należą do kompetencji rządu. Powoływany przepis zakłada co prawda konieczność zawarcia przez rząd porozumienia z organem banku centralnego, jednakże nadal inicjatywa należy do rządu. Rozwiązanie to wpływa w sposób ograniczający na niezależność $\mathrm{NBP}^{29}$.

\section{NIEZALEŻNOŚĆ A ZAKRES ODPOWIEDZIALNOŚCI NBP}

Polskie unormowania prawne sytuują NBP w gronie najbardziej niezależnych banków centralnych na świecie. Analizując zagadnienie niezależności banku centralnego, zwraca się uwagę na trzy aspekty owej autonomii: personalny, finansowy i funkcjonalny. NBP dysponuje w znacznym zakresie niezależnością personalną. Świadczy o tym brak formalnego wpływu rządu na obsadę organów banku, kadencja Prezesa NBP oraz członków Rady Polityki Pieniężnej (6 lat) dłuższa niż kadencja rządu (art. 227 Konstytucji RP), a także istotne ograniczenia możliwości skrócenia owej kadencji (art. 9 i 13 ustawy o NBP).

Niezależność finansowa wymaga ustawowego ograniczenia zakresu finansowania przez bank wydatków budżetowych. Obecnie Konstytucja RP zabrania bezpośredniego finansowania przez bank centralny deficytu budżetowego (art. 220). Taki przepis zmienia relacje między rządem i ministrem finansów a NBP. Wcześniej, gdy przepisu tego nie było, organy te próbowały wywierać nacisk na bank centralny w kwestii finansowania deficytu budżetowego ${ }^{30}$.

Niezależność funkcjonalna wyraża się w zagwarantowaniu bankowi centralnemu prawa do samodzielnego kształtowania i realizowania polityki pieniężnej. Jest ona za-

29 R. Huterski, Niezależność banku centralnego, Toruń 2000, s. 198; R. Tupin, Niezależność NBP a obowiązek dbatości o stan gospodarki narodowej (uwagi krytyczne i wnioski de lege ferenda), „Przegląd Ustawodawstwa Gospodarczego" 2002, nr 6, s. 14-15; C. Kosikowski, Publiczne prawo bankowe, Warszawa 1999, s. 300.

30 I. Kraś, Powstanie i status Narodowego Banku Polskiego, „Seminare” 2006, nr 23, s. 219, [online] http:// www.seminare.pl/pdf/tom23-16-kras.pdf, 28 II 2014. 
pewniona przez skupienie w NBP zadań związanych z tworzeniem, realizacją i odpowiedzialnością za prowadzenie polityki pieniężnej. Zgodnie z obecnym stanem prawnym zadania te są realizowane na podstawie corocznej uchwały Rady Polityki Pieniężnej. Godny podkreślenia jest fakt, że to Rada decyduje każdorazowo o treści wspomnianej uchwały. Sejm jest „tylko” informowany. Zgodnie z art. 227 ust. 1 Konstytucji i art. 3 ustawy o NBP głównym zadaniem NBP jest walka z inflacją, a dopiero na drugim miejscu, jeśli nie jest to sprzeczne z celem podstawowym, wspieranie polityki gospodarczej rządu $^{31}$. Wysoki stopień niezależności NBP jest wskazanym rozwiązaniem ustrojowym przede wszystkim ze względu na konieczność zagwarantowania realizacji autonomicznej polityki pieniężnej, niezakłóconej przez ewentualne zmiany na scenie politycznej. Autonomia banku jest istotna w obliczu planów pełnego uczestnictwa Polski w strukturach Unii Europejskiej i przyjęcia wspólnej waluty, jak również światowego kryzysu finansowego. Niezależny bank centralny jako apolityczny organ państwowy jest gwarantem wartości polskiego pieniądza, który stanowi o silnej pozycji państwa na świecie oraz jest wyrazem stanu gospodarki kraju.

Działalność banku i jego organów musi jednak podlegać ocenie, ponieważ jest to działalność publiczna prowadzona w imieniu i na rzecz państwa. Wyzwaniem było połączenie odpowiednich form demokratycznej kontroli z zachowaniem określonej prawnie autonomii banku centralnego. Ustawodawca musiał odpowiedzieć na pytanie, kto i w jaki sposób ma oceniać działalność NBP. W Polsce przyjęto zasadę, że części tej oceny dokonuje Sejm poprzez system różnych sprawozdań składanych mu przez NBP. Najważniejsze z nich to:

- sprawozdanie z wykonania założeń polityki pieniężnej, które Rada Polityki Pieniężnej ma obowiązek złożyć w ciągu pięciu miesięcy od zakończenia roku budżetowego (art. 227 ust. 6 Konstytucji i art. 12 ust. 1 ustawy o NBP);

- roczne sprawozdanie z działalności NBP (art. 70 ustawy o NBP).

Co istotne, sprawozdania te nie podlegają zatwierdzeniu przez Sejm, lecz zgodnie z obowiązującym Regulaminem Sejmu RP Izba zapoznaje się z ich treścią; mogą się one również stać przedmiotem obrad (art. 124 i 169 Regulaminu Sejmu RP). W konsekwencji Sejm, realizując ten element oceny NBP i jego organów, zdaje się mieć nikłą możliwość wpływu na działania NBP. Nie oznacza to jednak, że organ ten nie próbował rozszerzyć zakresu swojej kontroli nad bankiem centralnym. 24 marca 2006 r. Sejm w drodze uchwały powołał komisję śledczą do zbadania rozstrzygnięć dotyczących przekształceń kapitałowych i własnościowych w sektorze bankowym oraz działań organów nadzoru bankowego w okresie od 4 czerwca 1989 r. do 19 marca 2006 r. Głównym zadaniem bankowej komisji śledczej miało być zbadanie działalności NBP, nadzoru bankowego oraz prywatyzacji sektora finansowego po 1990 r. Trybunał Konstytucyjny, już w trakcie prac komisji, wydawał wyrok ${ }^{32}$ w sprawie niezgodności z prawem zadań wyznaczonych bankowej komisji śledczej. Sędziowie uznali, że ko-

31 E. Frankowski, Wobronie niezależności banku centralnego, „Glosa” 2001, nr 2, s. 3.

32 Wyrok Trybunału Konstytucyjnego z 22 września 2006 r., sygn. akt U.4/06, M.P. 2006, nr 66, poz. 680. 
misja nie miała prawa kontrolować działań Narodowego Banku Polskiego oraz jego ówczesnego prezesa Leszka Balcerowicza, podobnie jak działań niektórych członków Komisji Nadzoru Bankowego. Trybunał podkreślił, że zasadniczym elementem statusu NBP jest jego niezależność od innych organów państwa ${ }^{33}$. Wyrok Trybunału Konstytucyjnego w znaczący sposób wpłyną na wizerunek państwa polskiego na świecie oraz na funkcjonowanie Narodowego Banku Polskiego. Po pierwsze, potwierdził, że Polska jako państwo prawa jest odporna na niezgodne z prawem działania organów państwa i grup politycznych funkcjonujących w ich obrębie. Po drugie, potwierdził niezależność Narodowego Banku Polskiego i jego uprawnienie do realizacji autonomicznej polityki pieniężnej.

Kolejnym organem, który uczestniczy w nadzorze nad NBP, jest Rada Ministrów. To jej, zgodnie z art. 69 ustawy o NBP, Prezes NBP przedstawia roczne sprawozdanie finansowe do zatwierdzenia. Zaznaczyć jednak należy, że roczne sprawozdanie finansowe NBP badane jest przez biegłego rewidenta wybranego przez Radę Polityki Pieniężnej, a więc rola Rady Ministrów ogranicza się jedynie do zatwierdzenia tego dokumentu. Warto przypomnieć, że w pierwotnej wersji ustawy badaniem i oceną tegoż sprawozdania miała zajmować się komisja powołana przez Radę Ministrów na wniosek ministra finansów. Przepis ten został zmieniony w drodze ustawy z 18 grudnia 2003 r. i wskazuje na chęć wprowadzenia niezależnej, przeprowadzonej przez specjalistów kontroli finansowej NBP.

Kolejnym organem uprawnionym do przeprowadzania kontroli nad działalnością NBP jest Najwyższa Izba Kontroli, która - zgodnie z art. 203 Konstytucji oraz art. 2 ustawy o NIK - kontroluje działalność banku centralnego z punktu widzenia legalności, gospodarności, celowości i rzetelności ${ }^{34}$.

Znaczącym rozwiązaniem ustrojowym jest brak odpowiedzialności Rady Polityki Pieniężnej i Zarządu za podejmowane decyzje. Jedynie Prezes NBP, który przewodniczy obu tym organom, jest podmiotem ponoszącym odpowiedzialność prawną. Artykuł 198 Konstytucji stanowi, że Prezes NBP ponosi odpowiedzialność konstytucyjną przed Trybunałem Stanu za naruszenie Konstytucji lub ustawy, w związku z zajmowanym stanowiskiem lub w zakresie swojego urzędowania. Wniosek wstępny o pociągnięcie go do odpowiedzialności przed Trybunałem Stanu może zostać złożony Marszałkowi Sejmu przez Prezydenta lub grupę posłów w liczbie minimum 115 bądź sejmową komisję śledczą (art. 6 ust. 2-3 ustawy o Trybunale Stanu). Uchwała Sejmu o pociągnięciu do odpowiedzialności konstytucyjnej Prezesa NBP powoduje zawieszenie go w czynnościach. Jak słusznie zauważa Cezary Kosikowski, możliwa jest jednak sytuacja, gdy Rada bądź Zarząd podejmą uchwały wbrew stanowisku Prezesa NBP, który następnie poniesie odpowiedzialność za decyzje, z którymi się nie zgadza $^{35}$.

33 Por. E. Myślak, Selected Aspects of the Independence of the National Bank of Poland in the Context of Polish Political Practice, „Przegląd Politologiczny” 2013, nr 3.

34 C. Kosikowski, Finanse publiczne..., s. 257-259.

35 C. Kosikowski, Publiczne prawo..., s. 286, 288. 
Fakt ograniczonej kontroli NBP z jednej strony wydaje się słusznym rozwiązaniem gwarantującym realizowanie w pełni polityki pieniężnej niezależnej od zmian na scenie politycznej i wyników wyborów. Z drugiej jednak strony pojawiają się opinie o zakłóconej równowadze między niezależnością banku centralnego a jego odpowiedzialnością, o niewystarczającym uwzględnieniu przez ustawodawcę związku między autonomią NBP a demokratycznym nad nim nadzorem. Rozwiązaniem może być ograniczenie niezależności NBP, jednak takie zmiany we względnie młodej demokracji i przy zmieniających się ekipach rządowych mogłyby doprowadzić do ponownego uzależnienia banku od rządu i w efekcie zagrożenia dla długoterminowej polityki pieniężnej. Właściwsze wydaje się wzmocnienie odpowiedzialności banku oraz zwiększenie przejrzystości jego funkcjonowania ${ }^{36}$.

\section{WNIOSKI KOŃCOWE}

Bank centralny w Polsce w wyniku wprowadzonych unormowań prawnych oraz praktyki ustrojowej uzyskał status niezależnego organu konstytucyjnego. Przeprowadzona analiza wybranych aspektów pozycji ustrojowej banku centralnego w Polsce pozwoliła na potwierdzenie tezy o słuszności i celowości zastosowanych rozwiązań. Mimo że Narodowy Bank Polski nie odnajduje swego miejsca w monteskiuszowskim trójpodziale władz, zakres kompetencji i funkcji oraz konstytucyjne podstawy prawne uzasadniają w pełni jego obecną pozycję jako organu państwa. Pewnym ograniczeniem, jednak zamierzonym przez ustrojodawcę, jest odebranie organom banku prawa do wydawania norm prawnych powszechnie obowiązujących, spowodowane właśnie pozostawaniem NBP poza klasycznym trójpodziałem władz - władz, które na siebie wpływają poprzez wzajemną kontrolę swej działalności. Z przyjętych w Polsce rozwiązań prawnych wynika, że nadzór Sejmu i rządu nad działalnością NBP jest raczej skromny, a możliwość władczego oddziaływania na zmianę prowadzonej przez NBP aktywności są praktycznie żadne. Jednocześnie NBP nie podlega nadzorowi żadnego innego organu, oprócz kontroli ze strony Najwyższej Izby Kontroli. Bank centralny jest szczególnym organem państwa i dlatego w sposób szczególny należy go traktować. Jego cechą jest apolityczność i duża niezależność od władz państwowych, która skutkuje efektywnym wykonywaniem jego podstawowego zadania, czyli dbania o wartość polskiego pieniądza. Jednak rezultatem takiej formy uczestnictwa w życiu państwa jest ograniczona kontrola, jakiej podlega bank centralny. Wyposażenie jakiegokolwiek organu NBP w prawo do wydawania norm prawa powszechnie obowiązującego, przy braku wyżej wspomnianej kontroli, stałoby w sprzeczności z zasadą demokratycznego państwa prawnego.

W kwestii przyznanej Narodowemu Bankowi Polskiemu autonomii cenne jest odniesienie do modelu oceny niezależności banku centralnego autorstwa Alexa Cukiermana. Aż trzy z czterech zmiennych oceny niezależności personalnej banku dotyczą trybu powoływania i odwoływania jego prezesa. Analizują one okres urzędo-

36 A. Wojtyna, Szkice o polityce pieniężnej, Warszawa 2004, s. 219. 
wania, podmiot uprawniony do powołania oraz warunki odwołania prezesa. Czwarta zmienna odnosi się do możliwości - lub braku - sprawowania funkcji w rządzie przez prezesa banku centralnego. $\mathrm{Z}$ modelu tego wynika, że im dłuższy jest okres kadencji prezesa banku centralnego przewidziany przez prawo, tym wyższy stopień niezależności banku centralnego. Po drugie, im większy wpływ władzy politycznej (a zwłaszcza wykonawczej) na powołanie i odwołanie prezesa banku centralnego, tym niższy stopień niezależności banku centralnego. Po trzecie, zakaz prawny sprawowania funkcji w rządzie przez prezesa banku centralnego zwiększa stopień jego niezależności. Ponieważ cele rządu są przeważnie krótkookresowe, co wynika z okresu sprawowanej przezeń władzy, w przeciwieństwie do celów banku centralnego, niezależność banku wzrasta odwrotnie proporcjonalnie do jego zależności od władzy wykonawczej ${ }^{37}$. Analiza, zgodnie z modelem Cukiermana, polskich unormowań prawnych, wykazuje, że bank centralny uzyskuje wysoką pozycję w zakresie niezależności personalnej. Służąca zagwarantowaniu apolityczności długa, sześcioletnia kadencja Prezesa zapewnia ciągłość i autonomię funkcjonowania banku centralnego niezależnie od zmieniającej się rzeczywistości politycznej. Brak dodatkowych funkcji Prezesa w rządzie oraz sposób jego wyboru dodatkowo wpływają na autonomię banku. Jedynie kwestia niezaangażowania rządu w tryb wyboru Prezesa NBP rodzi pewne wątpliwości. Mimo bezpośredniego braku udziału Rady Ministrów w tym procesie, biorąc pod uwagę zasady funkcjonującego w Polsce systemu parlamentarno-gabinetowego, partie reprezentowane w rządzie mogą wpływać na wybór omawianego organu NBP poprzez swoją reprezentację w Sejmie.

Na koniec warto podkreślić, że ustawa o NBP słusznie - jak wskazuje Cezary Kosikowski - zobowiązuje Narodowy Bank Polski do współdziałania z innymi organami w kształtowaniu i realizacji polityki gospodarczej państwa, lecz jeszcze słuszniej zastrzega, że nie może ono naruszać realizacji założeń polityki pieniężnej. Dodatkowo należy dostrzec pewne uwarunkowania, które towarzyszą działaniom rządu, Sejmu oraz NBP jako centralnemu bankowi państwa. Organy państwowe muszą z natury rzeczy podejmować decyzje polityczne i społeczne w sprawach ekonomicznych, ponieważ inaczej zawiodą oczekiwania wyborców. Natomiast NBP może i musi działać inaczej, ponieważ nie jest odpowiedzialny za realizację polityki gospodarczej rządu. Powinnością NBP jest natomiast dostarczanie społeczeństwu obiektywnych argumentów ekonomicznych uzasadniających lub nie politykę gospodarczą rządu ${ }^{38}$.

37 G. Paluszak, Pojęcie niezależności banku centralnego i jej typy, [w:] Bankowość w okresie przemian systemowych. Wybrane zagadnienia, red. nauk. W. Przybylska-Kapuścińska, Poznań 1998, s. 22-33, Zeszyty Naukowe - Akademia Ekonomiczna w Poznaniu, Seria 1, z. 262; A. Cukierman, S. Webb, B. Neyapti, Measuring the Independence of Central Banks and its Effect on Policy Outcomes, „The World Bank Economic Review" 1992, Vol. 6, nr 3, s. 358-359, [online] http://www.cedeplar.ufmg.br/economia/disciplinas/ecn933a/crocco/Operacao_governanca_Bancos_Centrais/CUKIERMANAWEBBNEYAPTIMeas.pdf, 10 XI 2013. 


\section{BIBLIOGRAFIA}

Bankowość w okresie przemian systemowych. Wybrane zagadnienia, red. nauk. W. Przybylska-Kapuścińska, Poznań 1998, Zeszyty Naukowe - Akademia Ekonomiczna w Poznaniu, Seria 1, z. 262.

Bień-Kacała A., Witkowski Z., O potrzebie redefinicji terminu „organ państwa”, [w:] W stużbie dobru wspólnemu. Księga jubileuszowa dedykowana Profesorowi Januszowi Trzcińskiemu, red. R. Balicki, M. Masternak-Kubiak, Warszawa 2012.

Cukierman A., Webb S., Neyapti B., Measuring the Independence of Central Banks and its Effect on Policy Outcomes, „The World Bank Economic Review” 1992, Vol. 6, nr 3, [online] http:// www.cedeplar.ufmg.br/economia/disciplinas/ecn933a/crocco/Operacao_governanca_ Bancos_Centrais/CUKIERMANAWEBBNEYAPTIMeas.pdf.

Frankowski E., W obronie niezależności banku centralnego, „Glosa” 2001, $\mathrm{nr} 2$.

Huterski R., Niezależność banku centralnego, Toruń 2000.

Kaszubski R. W., Narodowy Bank Polski - centralny organ państwa, „Glosa” 1995, nr 10.

Knosala E., Stasikowski R., Status Narodowego Banku Polskiego w systemie organów państwa, „Przegląd Sejmowy” 2010, nr 1.

Konstytucja Rzeczypospolitej Polskiej z dnia 2 kwietnia 1997 r., Dz. U. 1997, nr 78, poz. 483. Konstytucyjność regulacji Rady Polityki Pieniężnej i NBP, Orzeczenie TK, „Glosa” 2000, nr 11. Koperkiewicz-Mordel K., Polski bank centralny w świetle nowej Konstytucji i ustawy o Narodowym Banku Polskim, „Bank i Kredyt” 1998, nr 3.

Kosikowski C., Finanse publiczne $w$ świetle Konstytucji RP oraz orzecznictwa Trybunatu Konstytucyjnego (na tle porównawczym), Warszawa 2004.

Kosikowski C., Pozycja Narodowego Banku Polskiego i jego organów w prawie polskim, „Państwo i Prawo" 2002, nr 11.

Kosikowski C., Publiczne prawo bankowe, Warszawa 1999.

Kraś I., Powstanie i status Narodowego Banku Polskiego, „Seminare” 2006, nr 23, [online] http:// www.seminare.pl/pdf/tom23-16-kras.pdf.

Kulesza M., „Źródta prawa” i przepisy administracyjne w świetle nowej Konstytucji, „Państwo i Prawo" 1998, nr 2.

Machelski T., Charakter prawny Rady Polityki Pienięznej, „Przegląd Legislacyjny” 2009, nr 3/4.

Machelski T., Stanowienie polityki pieniężnej w Polsce na tle instytucjonalnych standardów bankowości centralnej, „Problemy Współczesnego Prawa Międzynarodowego, Europejskiego i Porównawczego" 2010, Vol. 8.

Mikos A., Ustrojowa pozycja banku centralnego w Polsce, Warszawa 2006, Monografie Prawnicze.

Myślak E., Selected Aspects of the Independence of the National Bank of Poland in the Context of Polish Political Practice, „Przegląd Politologiczny” 2013, nr 3.

Niemierka S., Pozycja Prezesa NBP w „ustawach bankowych”, „Glosa” 1998, nr 8.

Orzeczenie Trybunału Konstytucyjnego z dnia 13 września 1990 r., sygn. akt U. 4/90, Z.U. 1990/10.

Orzeczenie Trybunału Konstytucyjnego z dnia 13 września 1990 r., U. 4/90, [online] http:// www.trybunal.gov.pl/orzeczenia/teksty/otkpdf/1990/U_04_90.pdf. 
Paluszak G., Pojęcie niezależności banku centralnego i jej typy, [w:] Bankowość w okresie przemian systemowych. Wybrane zagadnienia, red. nauk. W. Przybylska-Kapuścińska, Poznań 1998, Zeszyty Naukowe - Akademia Ekonomiczna w Poznaniu, Seria 1, z. 262.

Szmyt A., W sprawie uprawnień prawodawczych organów Narodowego Banku Polskiego, „Przegląd Sejmowy" 1998, $\mathrm{nr} 6$.

Tupin R., Niezależność NBP a obowiązek dbatości o stan gospodarki narodowej (uwagi krytyczne $i$ wnioski de lege ferenda), „Przegląd Ustawodawstwa Gospodarczego” 2002, nr 6.

Tupin R., Status prawny i kompetencje prawotwórcze organów Narodowego Banku Polskiego i Komisji Nadzoru Bankowego, „Przegląd Ustawodawstwa Gospodarczego” 1998, nr 7-8.

Ustawa z 7 listopada 2008 r. o Komitecie Stabilności Finansowej, Dz. U. 2008, nr 209, poz. 1317.

Ustawa z 23 grudnia 1994 r. o Najwyższej Izbie Kontroli, Dz. U. 1995, nr 13, poz. 59.

Ustawa z 26 marca 1982 r. o Trybunale Stanu, Dz. U. 1982, nr 11, poz. 84.

Ustawa z 29 sierpnia 1997 r. o Narodowym Banku Polskim, Dz. U. 1997, nr 140, poz. 938 ze $\mathrm{zm}$.

Ustawa z 29 sierpnia 1997 r. Prawo bankowe, Dz. U. 1997, nr 140, poz. 939.

Ustawa z 31 stycznia 1989 r. o Narodowym Banku Polskim, Dz. U. 1989, nr 4, poz. 22.

Wojtyna A., Szkice o polityce pieniężnej, Warszawa 2004.

Wyrok Trybunału Konstytucyjnego z 22 września 2006 r., sygn. akt U.4/06, M. P. 2006, nr 66, poz. 680 .

Wyrok Trybunału Konstytucyjnego z 26 maja 1998 r., K. 17/98, [online] http://www.trybunal. gov.pl/orzeczenia/teksty/otkpdf/1998/k_17_98.pdf.

Wyrok Trybunału Konstytucyjnego z 26 maja 1998 r., sygn. akt K. 17/98, Dz. U. 1998, nr 67, poz. 446.

Wyrok Trybunału Konstytucyjnego z 28 czerwca 2000 r., K. 25/99, [online] http://www.trybunal.gov.pl/orzeczenia/teksty/otkpdf/2000/k_25_99.pdf.

Wyrok Trybunału Konstytucyjnego z 28 czerwca 2000 r., sygn. akt K. 25/99, Dz. U. 2000, nr 53, poz. 648.

Zdebel M., Status konstytucyjny Narodowego Banku Polskiego, [w:] Ksiega pamiatkowa profesora Marcina Kudeja, red. nauk. A. Łabno, E. Zwierzchowski, Katowice 2009.

Zubik M., Narodowy Bank Polski (analiza konstytucyjno-ustrojowa), „Państwo i Prawo” 2001, nr 6 .

Dr Ewa MYŚLAK - absolwentka politologii, europeistyki oraz Międzywydziałowych Studiów Amerykanistycznych na UJ; doktor nauk humanistycznych w zakresie nauk o polityce; asystent w Katedrze Współczesnych Systemów Politycznych w Instytucie Nauk Politycznych i Stosunków Międzynarodowych UJ; członek Grupy Badawczej „Inicjatywa Helwecka”. Główne obszary jej zainteresowań badawczych to systemy polityczne, instytucje demokracji bezpośredniej oraz bankowość centralna. Jest autorką monografii Narodowy Bank Polski w systemie ustrojowym Rzeczypospolitej Polskiej (Kraków 2013) oraz wielu artykułów i opracowań poświęconych wspomnianej wyżej tematyce. 